\title{
Public Service Media and Parliaments: How the Two Institutions Can Collaborate and Promote Public Values in a Democracy (The European Perspective)
}

\author{
Bissera Zankova \\ “Media 21" Foundation, Bulgaria
}

\begin{abstract}
Public service media (PSM) are linked to a variety of bodies and function in a setting in which various stakeholders participate. The article deals with the issue of the relationships between public service media and parliaments as two public institutions indispensable to democracy. They have to be independent, to act to the interest of society and to initiate and sustain an open democratic debate enabling a diversity of voices to be heard. Conspicuous is their characteristic to integrate groups and communities around commonly shared values and to promote human rights. The discussion dwells on the direct and indirect relationships that expand between public service media and parliaments and makes conclusions about the principles that have to be put in practice in order for the democratic dialogue between the two to be strengthened.
\end{abstract}

Keywords: public service media, parliaments, public service values, dialogue between public bodies, democratic institutions

\section{Introduction}

The rapid changes in the digital age have brought forth debates not only about the fate of public service media but also about the relationships that develop between public media organizations and other democratic institutions.

Performing an essential public mission public service media provide important communication reflecting the work of various bodies and organizations in the state and bring their activities closer to the citizens. Summarizing a solid amount of data the EBU research paper on parliament broadcast services in Europe sheds light on the process and makes the conclusion that "PSM has a strong role in providing citizens with parliamentary coverage, both via dedicated and non-dedicated broadcast services" (EBU parliamentary broadcast: 3 ).

At the same time public media are more than information conduits in a democracy. Already in 2012 the Council of Europe stressed that public service media organisations are linked to a variety of bodies and structures and operate within a regulatory framework that "sets out the responsibilities of the different parties involved: government, parliament, regulatory authorities (including auditing and other inspectorates) and the public service media themselves, as well as any specified engagement from designated third parties (civil society, market representatives, etc.) (Council of Europe Declaration and Recommendation (2012)). 
These well-known conclusions flow even more unconditionally from a recent EBU report on the public service media (PSM) correlations in a democracy. They prove that strong public service media are essential for building healthy societies being related to their foundations through "democratic governance, social cohesion and citizens' trust in the media system" (EBU correlations).

In the digital age public service broadcasting organizations inevitably undergo transformations as well as their relations with other stakeholders. Taking these into account it is worth discussing how legislative bodies through their functions can guarantee (or undermine) the position of public service media and prospects for the future nowadays.

The purpose of this article is to explore various aspects of the relationships between public service media and parliaments as core democratic institutions and to formulate some proposals that can enhance their interaction to the public benefit.

\section{Some Examples of the Problems of PSM Regulation}

Since 2010 an array of alarming developments in the European (and other countries) has taken place in the media field with respect to public service media. Speedy, biased and non-transparent reforms have been implemented through legislative or governmental initiatives jeopardizing their very existence.

In its Resolution 1920 (2013) "The state of media freedom in Europe" the Parliamentary Assembly of the Council of Europe expresses its great concern about the cases of encroachment of media freedom in Europe. This undesirable situation has occurred not without the interference of parliaments implementing unsuccessful changes in the public media system. Stressing that "freedom of expression and information constitutes a cornerstone of good governance and thriving democracy, as well as a fundamental obligation of each member State under Article 10 of the European Convention on Human Rights (ETS No. 5, "the Convention")" the Parliamentary Assembly notes with concern recent reports about political pressure on public service broadcasters in Hungary, Italy, Romania, Serbia, Spain, and Ukraine. It also points explicitly to the approach in Georgia and the pressure put on a public service broadcaster through the introduction of controversial amendments to the law on broadcasting. ${ }^{1}$ The Assembly refers particularly to its seminal Resolution 1636 (2008) on indicators for media in a democracy which provides that "public service broadcasters must be protected against political interference in their daily management and their editorial work; senior management positions should be refused to people with clear party political affiliations" (PACE Resolution 1636 (2008)) .

The Hungarian media reforms from 2010 affected deeply all types of media and provoked wide international criticism. A resolution adopted by the European Parliament in March 2011 raised the admonition that the legislation contravenes OSCE and international "standards by doing away with the political and financial independence of public-service media". The changes considered antidemocratic by international organizations made Freedom House to downgrade Hungary's status from "Free" to "Partly free" country after being included in the former category for over a decade (Shekhovtsov, 2016, p. 6). The crux of the reforms in question comprised, on the one hand, the centralization of the media system by merging the National Radio and Television Commission with the National Media and Communication Authority to create a mega body - the

\footnotetext{
1 The then Prime Minister suggested merging the Georgian public service broadcaster with the private broadcaster TV9 owned by his wife. The plan was preceded by a series of surprise financial inspections of the Georgian public broadcaster, following aggressive political statements by senior government officials in parallel with the introduction of controversial amendments to the law on broadcasting (PACE Resolution 1920 (2013)).
} 
National Media and Infocommunications Authority (NMHH) the president of which is appointed by the president of the country upon the recommendation of the prime minister, for indefinitely renewable nine-year terms and possessing vast competences and fusing all the assets of the three public-service media companies (MTV, Duna TV, and Hungarian Radio) and the National News Agency (MTI) under the auspices of the Media Support and Asset Management Fund, supervised by the Media Council, on the other. Under this law public broadcasters do not have the right to produce their own news and are obliged to use the news produced by the MTI. In addition, the Fidesz-controlled parliament has amended the Hungarian constitution so as to remove the previous ban on information monopolies (Polyák, 2015).

In December 2015, the Polish Government started actions aiming at placing public service media broadcasters under its close political control. A provisional law of December 2015 empowered the Ministry of State Treasury to appoint and dismiss PSM's senior management and boards of directors. In June 2016, another law transferred these competences to a new regulatory institution, the National Media Council though the decision of the Constitutional Court of 13 December 2016 mandates the government to swiftly adopt appropriate legislative changes to restore the full competences of the National Broadcasting Council - the regulatory authority recognised by the Constitution. Throughout 2016, public radio and television personnel have been under considerable pressure to refrain from criticising the methods of the governance and operation of the PSM (Herman, 2016). The European Union observers outside Poland have sharply criticized the new media mechanism. In a joint report ARTICLE 19 and the Polish Helsinki Foundation for Human Rights (HFHR) express their mutual concerns regarding the independence of public service media in Poland (Article 19, 2017).

In 2016 the Romanian parliament abolished the license fee for public radio and television thus modifying its funding to rely on state funds only. According to the statement of the EBU issued on the occasion "public service media is already in a fragile state in Romania with TVR, in particular, suffering from a highly politicized governance structure where the president is appointed by parliament and routinely dismissed each year" (Paun, 2016).

The South East European Media Observatory, a regional civil society organization, reports in March 2017 that "the formerly state-run broadcasters, albeit transformed at the formal level into public service media, were quickly taken over by political elites. This gave rise to a specific form of party domination within media, where the governing, managing and editorial positions were reserved for personnel loyal to those in power" (Petkovic \& Hrvatin, 2017).

In the publication experts particularly stress the lack of independence governance in the public media in the region. The parliaments have a dominant role in the appointment procedures of PSM governing bodies in all countries of the South East Europe, except in Serbia where the appointment is done by the Council of the Regulatory Authority of Electronic Media. The composition of the governing bodies appointed in the parliament, however, reflects the interests of the political majority (Ibid.).

Similar and other problems can be observed with respect to the public radio and television in the Southern Mediterranean Region. Reforming public media was not something that has been considered to be of crucial importance for the Southern Mediterranean countries. This phenomenon came to the fore as a result of the changes at the beginning of 2011 which brought in the wave of democratization. However, when assessing the performance of these newly emerging public media, it becomes evident that most of them do not appear able to perform the function assigned to them. Other challenges such as the collapse of state power, for example in Libya and Syria, the interventions from the executive branch hoping to maintain some control over public 
media system in Tunisia and Morocco, the lack of clarity around the independence of state-funded media and the difficulties generated by terrorism and security threats which made some governments turn to the media to play a supporting role in their fight war, such as is the case in Egypt, for example, brought planned reforms to a halt and imperiled the fragile democracy (Medmedia, 2017).

The shutting down of the Greek public broadcaster ERT with the government's decision in June 2013, though keeping broadcasting online, and finally being reopened in 2015 and the current drama about the possible closing of the Radio and Television of Bosnia-Herzegovina (BHRT) due to the lack of sustainable funding are two more examples of the pressure and intimidation put on public service media through legislative or governmental actions.

Reflecting on all these negative tendencies the Commissioner for Human Rights of the Council of Europe states that "the situation on the ground gives rise to concerns" due to "... insufficient safeguards in the legislation against political bias, or the lack of appropriate funding to guarantee the independence of the public broadcasters" (Muižnieks, 2017). ${ }^{2}$

All these instances illustrate the significance of the relationships established between public service media and other organizations and bodies, parliaments in particular, which should be rooted in the mutual respect of their independence and specific roles. The broader view on the checks and balances in the modern states demands cooperation and communication between various bodies and institutions. Such approach also calls for the careful consideration of their place, role and channels for efficient interaction in the democratic society. We shall proceed further on the topic by comparing the public service media and parliaments searching for characteristics that can serve as a common ground of collaboration.

\section{Public Service Media and Parliaments - A Comparison}

Public service media and parliaments are two institutions indispensable to the democratic system. They have to be independent, to represent the plurality of opinions and to serve best the public interest. There is a lot in common between the values endorsed by parliaments and the values that should guide public service media. However, significant differences also exist between the two. Parliaments possess state competences while public service media are public institutions and comprise an element of the media system. In the decision of 23 September 2003 in the Radio France and others case the European Court of Human Rights (the Court) underlined that public service broadcasters can be qualified as "non-governmental organisations" in the meaning of Article 34 of the Convention and can therefore apply to the Court. ${ }^{3}$

\footnotetext{
${ }^{2}$ This is not the only alert in this respect, see also Nidžara Ahmetašević and Tea Hadžiristić, The Future of Public Service Broadcasting in Bosnia and Herzegovina, also South East European network for the Professionalization of Media, Partial solutions for saving broadcasting service in Bosnia and Herzegovina, Marco Davor, The future of public service broadcasting in the Western Balkans: The need for a new paradigm, stating that public service broadcasters in the countries of the Western Balkans - Albania, Bosnia and Herzegovina, Croatia, Kosovo, Macedonia, Montenegro, and Serbia - are in crisis and in never ending transition, etc.

${ }^{3}$ Radio France and others v. France, admissibility decision of 23 September 2003, No. 53984/00. The Court defines the term on the basis of the Convention's case law relating to the question of whether territorial authorities and other public law entities should be qualified as "governmental organisations": "[...] the category of 'governmental organisation' includes legal entities which participate in the exercise of governmental powers or run a public service under government control. In order to determine whether any given legal person other than a territorial authority falls within that category, account must be taken of its legal status and, where appropriate, the rights that status gives it, the nature of the activity it carries out and the context in which it is carried out, and the degree of its independence from the political authorities" (Ibid.).
} 


\section{Public Institutions}

Parliaments and public service media perform important public functions in a democracy. Parliaments are legislative, controlling and deliberative bodies in the system of democratic government. They represent the legislative branch of the state, seen in modern democracies as "the quintessential form of representative government" (Dorsen, Rosenfeld, Sajo, \& Baer, 2003, p. 222). Sajo considers parliament "the fundamental institution of a constitutional system" not only because of its popular election but because the institution of the legislature "exists independently of all external forces and state institutions" (Sajo, 1999, p. 121). In a democratic society parliaments are expected to serve the whole of society providing a forum for various ideas and platforms to be heard.

The forum characteristic can also be labeled as a specific feature of public service media. Jakubowicz (2011) claims the purpose of public service broadcasting is "primarily as a public sphere and civil society institution with a specific programming remit and philosophy" (p. 33). If all media perform a publicly relevant watchdog function in democratic societies, "the public service media function is of special caliber due to the broad remit they discharge" (Zankova, 2014, p. 129).

Public service media target all individuals, social groups and communities, i.e., society at large. Speaking about "The public service broadcasting - the German example" Prof. Eberle argues that "PSB in Germany is a matter of society, the broadcasting institutions act as some kind of trustees for the society. The organization of PSB corresponds with and reflects that role" (Eberle, 2002, p. 1). His conclusion is valid for public service media in other countries, too.

Parliaments and public service media are national institutions closely associated with national tradition. For instance, the participants in a survey focusing on the $\mathrm{BBC}$ unique characteristics and place considered that being a British institution is a core part of the BBC's identity being integral to British society (BBC distinctiveness, 2017, pp. 11-13). Perceptions of the BBC as a national institution were also related to its status as a publicly-funded broadcaster, i.e., a media belonging to the public.

\section{Serving Democracy}

Parliaments guarantee the legitimacy of state power and how it is implemented. This depends on "the effectiveness with which parliaments carry out their constitutional and statutory competences" which ensures "the desirable quality of legitimacy in the democratic process" (Jędrzejowska, 2012, p. 5).

The legislative function pertains to the law-making process through which the will of the people is transferred into the will of a state in the form of a law, which has superior (after Constitution) legal force. "The legislative body as representative body to a greater degree corresponds to the demands of the democracy. The representative bodies fulfil this task as step by step through different procedures different political forces come to an agreement as the state must functioning in the interest of all people", concludes Bogdanovskaia (Bogdanovskaia, 1999).

Parliaments also exert control over the executive branch holding it accountable for its daily business but as representatives of peoples' interests they can scrutinize other bodies, agencies or public institutions.

Individuals may unite in political parties, associations and civil organizations to defend their interests and collectively express their position on matters of public concern. Parliaments should take into account these views and contribute to the formation of public opinion.

The role of public opinion is essential for promoting popular will in a democracy. Nowadays public 
opinion in society is mainly aggregated and distributed through the media. In the democratic state the media including public service media is not only a mere conduit of opinions and information but a powerful player in the public debate enhancing deliberative democracy. ${ }^{4}$ However, the media impact is crucial to the smooth functioning of democracy if media outlets and journalists are free from corporate and political pressures.

From all PSM functions in a democracy the dialogic mission supporting the processes of deliberation and public debate merits particular attention. According to Jakubowicz this includes "pluralistic participation and sociocultural as well as programmatic inclusiveness" (Jakubowicz, 2013a, p. 187).

The benefits of the public service approach are inherent in its unbiased reporting, pluralism and high quality programming thus uniting people through the general discourse for the general good.

\section{Promoting Values}

The law-making process and the role of the legislative bodies in it are based on the constitutional principles of democracy, separation of powers, equal representation, transparency and accountability. The acts of these bodies are adopted in an open and democratic manner and different political and social groups may to a greater or to a lesser degree influence it. From a broader perspective parliaments are a place of "debate, of political education, of the shaping of public opinion, indeed, of forming the general will through debates" (Sajo, 1999, p. 133). Through their activities parliaments have to promote and entrench public values as openness, transparency, equality, accountability, pluralism. The Inter-Parliamentary Union which is an organization of all parliaments around the world proclaims a vision of parliaments that are fully "representative, transparent, accessible, accountable and effective".

An unalienable characteristic of public service media is that they serve fundamental public values. The Amsterdam protocol from 1997 identifies the core features of PSB/M as "the system of public broadcasting in the Member States is directly related to the democratic, social and cultural needs of each society and to the need to preserve media pluralism... ". In 2012 the EBU members from Europe and beyond adopted unanimously six key values which define why public service media are indispensable in true democratic societies: universality, independence, excellence, diversity, accountability and innovation (EBU Public Service Values).

\section{Promoting Human Rights}

Via their legislative function parliaments determine the content of human rights and the procedures for their protection. By scrutinizing the actions of the executive and other institutions parliaments oversee the process of the implementation of these rights. Parliaments may also structure or take part in the devising of special agencies and bodies to perform a controlling function.

As a communication, democratic and cultural institution PSM is an essential instrument for constitutionalism, rule of law and human rights. (Boev, 2011). Above all public service media facilitate the exercise of the right to freedom of expression and information, however, due to their extensive remit these media support the implementation of other rights as well such as democratic participation, cultural and educational rights. Public media are also a major factor for the promotion of the rights of minorities, for the

\footnotetext{
4 The understanding of democracy as a deliberative democracy can be traced back in time to the Aristotle's notion of politics and the beliefs of the American founding fathers. "Above all, the American Constitution was designed to create a deliberative democracy. Under that system, public representatives were to be ultimately accountable to the people; but they would also be able to engage in a form of deliberation without domination through the influence of factions", claims Cass Sunstein (Sunstein, 1994, pp. 53-55). The theory of Jurgen Habermas about the public sphere is considered the most influential contemporary theory of deliberative democracy based on the equal rights and obligations of citizens. For presenting the conception of deliberative democracy and a critical review see, for instance, Lubenow (Lubenow, 2012).
} 
representation of and bringing to the fore the interests and claims of diverse communities and social groups. In this respect the EBU's research paper Correlations links between public service media and societal well-being is instructive to the fact that in countries with a strong PSM there is a high degree of press freedom and higher voter turnout than in other countries with weaker PSM (EBU correlations). This data is premised on the public function these media perform and the values they are committed to and actively pursue.

Compared to each other public service media and parliaments possess common features with regard to their social role and functions but their status is different - while parliaments implement power through the political process, PSM without being immune from politics wield information and communication power. Both are public bodies that have to be independent, to act to the interest of the whole of society and to initiate and sustain an open democratic debate enabling a diversity of voices to be heard. Conspicuous is their characteristic to integrate communities and persons around commonly shared values and to promote them in the democratic practice.

\section{Relationships Between Parliaments and Public Service Media}

Two types of relationships develop between parliaments and public service media depending on the impact that the actions of parliament may have over the organization and functioning of public service media-direct and indirect relationships. The former influences the structure and operation of the media without an intermediary body or process while the latter produces an effect through the activities of another body - the media regulatory authority.

\section{Direct Relationships: Legal Frameworks}

Organizational matters. Parliaments set out the legal framework for PSM according to the national legal tradition. Usually these pieces of legislation are complex ones. They provide for the status and the most important elements of the organization and supervision of the public media institution. According to Recommendation 96 (10) on the guarantee of the independence of public service broadcasting of the Council of Europe legislation should clearly endorse their editorial independence and institutional autonomy especially in key areas such as the definition of programming schedules, the conception and production of programmes, the editing and presentation of news and current affairs programmes, the organization of the activities of the service, recruitment, employment and staff management within the service, etc. (Council of Europe Recommendation 96 (10)).

Laws provide for the remit encompassing the obligations of PSM in a more detailed or a more general manner. ${ }^{5}$ It is explicitly pointed out that the remit serves the interests of the public at large.

Everywhere PSM programming (being their distinguishing feature) is qualified as programming of high quality. Nikoltchev correctly stresses that "programme quality considerations are almost always addressed. In most cases these developments go hand in hand with some form of adapting the structure of governing, monitoring, and/or supervising PSB" (Nikoltchev, 2013, p. 7).

Laws also envisage who will be in charge for the supervision of the media and how it will be implemented.

\footnotetext{
${ }^{5}$ Comparative research shows that some pieces of legislation can be more explicit than others. "In a large group of countries the basis of the remit of public service broadcasting (PSB) is in broadcasting law. This is the case for Denmark, Finland, UK (for S4C, Channel 4 and 5 who also have PSB-obligations), Ireland, the Netherlands, Austria, Spain, Portugal, Malta, Turkey, Latvia, Lithuania and Slovakia. In Germany the remit of the public service broadcasters is not explicitly specified by legislation. It is derived from Article 5 of the German Constitution as interpreted by the German Federal Constitutional Court. In Greece, Albania and Romania there is no remit, either in legislation or in another document" (Betzel, 2003, p. 1).
} 
The provisions governing the status and competence of the boards of management merit a particular focus. They should clearly state that these bodies are solely responsible for the day-to-day business of their organization and they should be guaranteed against any risk of political and economic interference. The supervisory bodies should not exercise any a priori control over programming. The PSM staff should be recruited, promoted and transferred without any dependence on origin, sex, opinions or beliefs or trade union membership.

All the principles are well known and widely shared through the years-long work of international organizations and courts. ${ }^{6}$ The authors of the comparative survey "Public service media according to constitutional jurisprudence - the human rights and constitutional law dimension of the role, remit and independence" come to the conclusion that "the implementation of freedom of expression and freedom of broadcasting falls - according to all countries' constitutional courts (France, Germany, Hungary, Italy, Poland and Spain - B.Z.) - within the competence of the legislator who is also obliged to observe certain requirements which mainly have the objective of ensuring media pluralism and enabling the public service broadcasters to fulfil their remit" (Public service media according to constitutional jurisprudence, 2009, p. 217). What matters most is how the legislative body will fulfill this task in practice.

The basic premise is that the laws regulating PSM should be devised having in mind that they are a factor for enhancing freedom of expression and that restrictions on freedom of expression are acceptable only under a limited and exhaustively enlisted number of conditions, if strictly formulated and pursuing other legitimate aims. In the same vein Boev suggests a rights-based approach to be undertaken by institutions and bodies with regard to PSM which means that "the main objective of governmental policies relating to PSM would be to respect, fulfil and protect human rights" (Boev, 2011, p. 146). The rights-based approach mandates that all state bodies at their level and within their competence should take into account human rights when tackling issues related to PSM. Parliaments in particular should strive to balance different rights and apply the principle of proportionality during the stage of the creation of legal norms well before their implementation.

The practical realization of these tenets of the public service media organization and operation are not respected appropriately everywhere. This happens either because laws are devised in a declarative manner without containing adequate guarantees or because existing laws are amended and supplanted by political majorities motivated by petty political and lobbies' interests (the recent Hungarian and Polish cases). Changes may happen also too frequently and selectively triggered by political parties and the situation in Bosnia and Herzegovina is illustrative of this. Genuine reforms in public service broadcasting in the Bosnian case have been painfully delayed and public service broadcasters have not been transformed into public service media simply to satisfy the interests of political elites. "Institutional instability and financial woes make the PSB system in BiH vulnerable to direct political interference when it comes to the appointment of managing boards, editors and even journalists", claim Ahmetašević and Hadžiristić (2016, p. 36).

\footnotetext{
${ }^{6}$ The Council of Europe has adopted a huge bulk of non-binding instruments developing the standards of the European Convention on Human Rights (ECHR) and the case-law of the European Court of Human Rights (ECtHR). The Courts of the European Union also recognise the important role of public service broadcasting in view of its cultural, social and democratic functions and its vital significance for ensuring democracy. The constitutional courts of the countries assign public service media an essential role for pluralism and democracy. Ultimately, though, national legislation has to respect the requirements resulting from the jurisprudence and legislation at the European level. However, national approaches and practices vary and under particular circumstances parliaments can act in a manner guided by political considerations only.
} 
Under some national systems parliaments directly elect the PSM supervisory boards. As national political bodies representing the public interest parliaments should exhibit restraint and escape political biases when exercising their discretion in the procedure. ${ }^{7}$ Political bargaining should step back and give way to public interest considerations.

The direct relationship of parliaments and PSM through the appointment of the supervisory boards can prove very controversial. It is not uncommon parties to send directly "loyal people" to sit there including family members. The same can happen if nominations are channeled through favoured civil society organizations to mislead public opinion.

The first condition that has to be in place is that the legal framework should establish clear, open and transparent procedures. The latter should respect pluralism - pluralism of backgrounds, race and gender. Requirements for appointment should not extend beyond the rules of non-compatibility and state explicitly the qualifications and qualities elected members should possess. They should be not only good professionals but personalities with high moral integrity that have the courage to defend PSM independence against political and business encroachment.

However, legal conditions are usually devised in a general and abstract manner and here is the role of parliaments to shape them adding more concrete details bearing in mind the role of public service media. With regard to this it is worth recalling the ECtHR observations in the case of Manole a.o. v Moldova (2009) which provide valuable guidance to the national legislator how to avoid flawed legal frameworks and fulfill its positive obligation best. The Court found that from February 2001 until September 2006 the Moldovan authorities violated freedom of expression by not sufficiently guaranteeing the independence of Teleradio-Moldova (TRM), the State-owned broadcasting company, which became a public broadcasting company in 2002. The current TRM Supervisory Board (SB), the judges stress, "although in theory its majority is formed by civil society, does not represent the whole spectrum of views prevalent in society, and in fact allows for political one-sidedness ... the SB ... includes two representatives from Parliament (one from the opposition), two from Government, two appointed by the President, and nine from different organisations. However, the President, the Government and Parliament are controlled by one party, and so are the majority of civil organisations represented on the board". The European Court of Human Rights recommends "the current law should be changed to allow for a different composition of the SB" ${ }^{8}$ A broader membership of the supervisory boards will not only strengthen PSM independence and legitimacy but also make these bodies really efficient and living up to the requirements of their public service mission.

Though the Manole case has become a well-known example across Europe, experts still report that the general picture of public media legislative drafting is not pinky. Tambini referring to the Mapping Digital Media Reports $(2009-2014)^{9}$ stresses the process of PSB policymaking is still "opaque, conflict-ridden and subject to capture by private interests" no matter how advanced are the media system and the democratic

\footnotetext{
${ }^{7}$ For instance, in the Check Republic the Czech Television Council (which consists of 15 members, with one-third of the members being replaced every two years) is nominated by parliament and reflects the political interests of the parties of the parliament. This controlling body is responsible for the approval of the budget and in addition deals with the appointment of the general director of the Check TV.

${ }^{8}$ Judgment by the European Court of Human Rights (Fourth Section), case of Manole a.o. v Moldova, Application no. $13936 / 02$ of 17 September 2009.

9 The Mapping Digital Media (MDM) project examines the global opportunities and risks generated by digitization. It encompasses 56 countries and provides an assessment how these changes affect the democratic function of the media and how they can promote open society values.
} 
governance structures (Tambini, 2015, p. 44). Civil society and international organizations involvement can be a positive factor to correct these disadvantages. "European institutions could advise on the drafting of media laws and regulations which would meet democratic standards and encourage rational and free public debate" (Shekhovtsov, 2016, p. 26). The latest developments in Bosnja where stakeholders have found an agreeable solution to resolve the PSB crisis that could cause the closure of the Bosnja and Herzegovina Radio and Television (BHRT) have also proven that international organizations, parliaments, politicians and civil society associations can put efforts together in the elaboration of up-to-date more effective public service media frameworks. The use of networks and the expertise they carry can be very helpful in this respect (Zankova, 2017, forthcoming)

Secure funding. The PSM funding mechanism is another crucial element the laws governing these media organizations should provide for. By and large the mechanism should be based on the principle that the state take on the responsibility to assure appropriate, secure and transparent funding which guarantees the accomplishment of the public service remit. Usually the implementation of the public function is assured through a variety of sources. There is no one specific financial mechanism that can be recommended and it is up to the countries to find arrangements to strengthen PSM sustainability. ${ }^{10}$

Under the Council of Europe Recommendation on the remit of public service media in the information society PSM content should be present on any platform or service and PSM laws should reflect the broader remit in the new media environment (Council of Europe Recommendation (2007)). The multiplatform operation of public media should be based on adequate and long-term financing. ${ }^{11}$ Though the Parliamentary Assembly of the Council of Europe calls on national legislators to decide on the specific mission, structure and funding of their public service broadcasters in accordance with national or regional circumstances and requirements practices are not promising everywhere (PACE Recommendation 1878 (2009)).

The transformation of public service broadcasters into public service media relates the problem of their funding to the proper settling of the digital media reforms. Digitization has not been successfully carried out in all countries, besides it can solve only partially the problems of PSM transformations. As the Mapping Digital Media Reports evidence "only in parts of Europe are public service media institutions strongly placed. Elsewhere, public service broadcasting is not understood as a concept and digitization has brought no pressure for reform" (Mapping Digital Media, 2014, p. 24).

The EBU guiding principles on PSM funding particularly emphasize that the PSM funding should reflect the dynamics of the developing broadcasting markets with more and more interactive digital services (Burnley, 2015 , p. 9). The paper underlines that public media funding has relied on a complementary set of sources so far but nowadays such mechanism has to be adjusted to the new digital conditions (Ibid.).

According to the declaration and recommendation on public service media governance the picture in Europe represents PSBs/PSMs which are at different stages of development. There are still public service broadcasters that have not become full-fledged digital players (Council of Europe Declaration and

\footnotetext{
10 The EBU Values Review The Tool formulating questions which can be used by countries for the evaluation of the implementation of the PSM values puts forward the following combination of sources of financing: taxes, licence fee, partly taxes; partly advertising, partly licence fee; partly advertising, other sources of funding/income (EBU Values Review: 5).

11 This objective is endorsed by the EU by the European Parliament resolution of 25 November 2010 on public service broadcasting in the digital era: The future of the dual system (2010/2028(INI)) which recommends that members states should "provide appropriate, proportionate and stable funding for public service media so as to enable them to fulfil their remit, guarantee political and economic independence and contribute to an inclusive information and knowledge society with representative, high quality media available to all”.
} 
Recommendation (2012)). Nikoltchev argues that "in many countries, we can witness reviews of the PSB remit or even the system of PSB as such ... In most cases these developments go hand in hand with some form of adapting the structure of governing, monitoring, and/or supervising PSB" (Nikoltchev, 2013, p. 7).

This process is uneven as in some countries laws on PSM are not attuned to the digital environment or provide for the PSM online remit in very general or vague terms (IRIS, 2015, p. 27). From the perspective of PSM digital offerings, Leurdijk (2006) claims that though PSBs expand their activities to digital platforms still legal restrictions and modest budgets undermine the stability of these projects (Leurdjk, 2006). The recent case of Bosnja is instructive how perilous the apathy of national parliaments can be if they do not take timely measures to transform the national public service broadcaster into a modern public service media institution. Referring to many Central and East European countries Car draws attention to the fact that "media policies on digital television development and its regulation are disregarded. At the same time, as the market adopts new technology, media digitization finds its own way to drive broadcasters to implement it. Croatia is also such an example. It is the Croatian public service broadcaster HRT that is expected to be the leader in this transformation process" (Car, 2007, p. 12). At the same time as in other countries in the region public service television is facing a program identity crisis and is fighting for stable financing.

Sometimes the changes of the sources of financing may prove problematic with respect to guaranteeing the independence of PSM and fostering its future activities. In Slovakia, for instance, until 2012 public service radio and television have been funded by a license fee. Effective from 1 January 2013, the PSB Radio and Television of Slovakia (RTS) has started being financed by an annual contribution from the State budget, which may be used only to cover the net costs of the public service mission. On the one hand, this amendment might be viewed as one to secure a stable budget for the public service but on the other, experts discern the establishment of a closer link to the government. "This arrangement promises to stabilize RTVS funding in the short term, but may expose the broadcaster to direct political meddling. Moreover, the amount earmarked for years after 2013 is based on RTVS current budgetary needs, but does not allow for improvement or development of program services in the future", Freedom House concludes in its country report about Slovakia. (Freedom House, 2012) A similar example is the already stated legal amendment of the public service media funding in Romania (see p. 3).

The data illustrates that the complex issues of PSM financing nowadays require an in-depth consideration of a plethora of details related to organization, management, programming, technological innovation including the impact new funding mechanisms may have on PSM freedom and independence. The transformations of the public media remit, the allocation of new budget sources and the improvement of the institutional design necessary for the adjustment to the requirements of the digital age can be delayed due to the lack of knowledge about the real influence of the information and communications technologies on the public service or political and economic reasons. Regarding this a clear understanding of the essential mission of PSM in the digital age and a pro-active approach on the part of the legislative bodies aiming at securing up-to-date regulation and novel funding opportunities are the steps needed.

Accountability channels. The pieces of legislation concerning PSM should provide also for the channels of its accountability. According to the Council of Europe recommendation on PSM governance PSM should be accountable to a variety of stakeholders but to the public above all. This goal can be achieved through different 
mechanisms provided by the law. ${ }^{12}$

Van den Bulck observes that PSM accountability arrangements vary across countries, however, parliamentary debate is usually there combined with other forms of accountability and "while direct accountability towards audiences remains by and large absent, audiences feature more prominently as an important factor in accountability measurements" (Van den Bulck, 2016, p. 79).

As bodies for wide deliberation and public opinion formation parliaments represent an important forum for the discussion of PSM mission and institutional efficiency. One of the channels of accountability regularly used is that PSM annual reports are submitted to parliaments, to the public, to the media regulatory authority and other bodies. These reports have to be accessible online as well. These are basic conditions.

The submission of the report as a formal step is not sufficient to trigger an effective controlling procedure and may be viewed as mere watering down of obligations. Its real value in a democracy is to be treated as an opportunity for the parliament and the public service media to step into discussion about essential media topics. More specifically parliaments as deliberative bodies have to take action and initiate an open and transparent debate on the annual reports of PSM. Further to this being also controlling bodies they have to adopt a decision making conclusions and providing recommendations if necessary. In this manner deliberation at parliaments should result in exercising parliamentary control over the activity of public service media. Parliaments can make proposals of a general nature through the decision but the latter should not be turned into an instrument for interference in the PSM business. As the participants in the conference "Public service media and democracy" (Prague, 10-11 November, 2016) have put it "PSM reports to the parliament should not be used as tools for political pressure or threats of dismissal".

This is a procedure for communication and exchange between two public bodies but not an impeachment procedure for the PSM governing boards. The parliament applies a values and rights oriented approach aiming at generating a freedom of expression enabling environment. If there are shortcomings in the discharge of the remit and in the media operation parliaments may decide to improve the law. These intentions should result in the beginning of an active dialogue with the public service media and the public at large based on the respect of the public service media autonomy. The democratic safeguards against ungrounded discretion of the legislative body in such cases are the openness, transparency and public involvement in the process of preparation of the draft.

Another form of accountability can be established at the level of the parliamentary committees. These committees especially the committees on culture, media and education may organize regular hearings concerning the discharge of the PSM remit and delve into issues pertaining to its social, cultural and educational implications. The parliamentary debate concerning the PSM performance can lend a broader dimension to the accountability measures applied thus bridging institutional accountability and accountability to the audience and to the citizenry at large because as Klinger correctly points out "effective and reliable accountability is central to the legitimacy and future of PSM" (Klinger, 2016, p. 205).

\section{Indirect Relationships}

Under some national systems parliaments elect or take part in the election of the members of the independent media authorities which represent buffer bodoes between public and commercial media, on the one

\footnotetext{
12 These can be governmental agreements, councils, commissions, ombudsmen. See in Boev (2011, p. 159). Also see Conde, N. PSM ombudsman, "Responsiveness and Accountability", paper presented during the consultation meeting of the Ad hoc Advisory Group on Public Service Media Governance, Strasbourg, 17 and 18 September 2009.
} 
side and the government, on the other. Often the membership of these bodies reflects the configuration of the parliamentary forces at the time of their election and the overall political climate in the country. The role of the independent media regulators is constantly discussed and considered problematic from the perspective of representative democracy. Schmitter and Trechsel, for instance, have proposed a scheme "to guard the guardians" placing the independent regulator back under the control of the government or the parliament. However, such move may bring even higher politicization of the body and to the whole of the media sector including public service media (Schmitter \& Trechsel, 2004). ${ }^{13}$

It is not unusual political forces to bargain seats on the body and instead of an independent authority that should take decisions on the basis of expert knowledge and experience a party-quota structure to be created. Basically these risks of the implementation of the election and appointment procedures should be taken into account by parliaments when drafting the broadcasting law and additional safeguards provided (qualified majority, mandate, professional requirements, civil society participation, etc.). Under some legal systems the independent media regulator enjoys a constitutional protection, but the development in Poland, for instance, are instructive that political majorities can be very inventive and circumvent even the basic law when they wish to impose their will (see p. 3).

Once appointed or elected the members of the media regulator become independent in their performance without being accountable for their single actions to the bodies that have appointed or elected them. They should not be perceived as representatives of the parliament or any other political force because otherwise the body will be jeopardized by "political capture". Hence the independence of public service media can be severely threatened.

In fact such independent regulators can operate at an arm's length from the government enjoying a sufficient level of independence and the general expectation is that they can serve as an institutional guarantee to avoid politicization of the media and economic groups' interference in their work. Vis-a-vis PSM "the legal framework should prescribe with sufficient clarity the responsibility of the regulator in relation to the public service media" (Council of Europe Recommendation (2012)).

In this respect the role of parliaments is crucial twice - once when shaping the media law which is critical for the setting up and functioning of the media regulator and second - when implementing the legal procedure and sending representatives to the body. In the ideal case if all democratic requirements are met throughout this process in which the public should also be involved, the independence of the media and the public service media in particular can be safeguarded best.

\section{Principles of Interaction Between PSM and Parliaments - Conclusion}

The relationships between PSM and parliaments in a democratic society expand broadly on two levels - as relationships between a governmental body and a media and as relationships between two public democratic institutions.

At the first level parliaments and media operate within a framework based on the principles of openness, speediness, innovation. More precisely parliaments are bound to act in an open and transparent manner when pursuing their activities as an important political priority with direct implications for democracy. This means

\footnotetext{
${ }^{13}$ See more in Jakubowicz, K. (2013b). Preface. Broadcasting regulatory authorities: Work in progress. In: W. Schultz, P. Walke, and K. Irion (eds.) The independence of the media and its regulatory agencies. Shedding new light on formal and actual independence against the national context. Intellect Bristol, UK, Chicago, USA. Kindle edition.
} 
making better use of a plethora of communications channels to bring their achievements closer to citizens, more particularly taking advantage of the new information technologies for speedy dissemination of information, creating online services of direct communication with people and providing full access to parliamentary documents before voting of the bill to set up the necessary conditions for a larger public scrutiny. ${ }^{14}$ Through the parliamentary broadcasts PSM facilitates the transparency of parliamentarian activities and strengthens their accountability before society.

As pivotal stakeholders in a democracy PSM and parliaments play an integrative role to communities, groups and persons. In the democratic system of checks and balances parliaments are not superior to public service media though they lay out the legislative framework for their creation and operation. For the sake of democracy the independent position of PSM as a key democratic, social and cultural institution should be guaranteed. Through the process of the establishment of regulatory frameworks parliaments can engage public opinion and the public at large. These instruments should be evaluated and amended through time on the basis of open and informed debate using international indicators and criteria.

In the digital society when horizontal communication expand the two public institutions should establish a regular exchange between themselves, a dialogue based on mutual respect, trust and cooperation for the entrenchment of human rights and freedom of expression in particular. A common goal for PSM and parliaments is to work consistently for the public good through the inculcation of a culture of independence of the democratic bodies and organizations which can be considered a "guarantee of the guarantees" for their genuine freedom and high public stature.

\section{References}

Ahmetašević, N., \& Hadžiristić, T. (2016). The future of public service broadcasting in Bosnia and Herzegovina. Retrieved September 20, 2017, from http://seenpm.org/future-public-service-broadcasting-bosnia-herzegovina/

Article 19. (2017). Poland: Independence of public service media, 31 Jan. 2017. Retrieved September 20, 2017, from https://www.article19.org/resources.php/resource/38628/en/poland:-independence-of-public-service-media

BBC Distinctiveness. (2017). Report prepared for Ofcom. Ipsos Mori Social Research Institute. Retrieved September 20, 2017, from https://www.ofcom.org.uk/_data/assets/pdf_file/0025/102958/bbc-distinctiveness-ipsos-mori.pdf/

Betzel, M. (2003). Programme performance of public service broadcasting and its mission in the digital age: A survey presented at the 17th EPRA meeting. Retrieved September 20, 2017, from https://www.epra.org/attachments/naples-wg-1-programme-performance-of-psb-background-paper/

Boev, B. (2011). Public service media and human rights. In Human rights and a changing media landscape (pp. 133-175). Strasbourg, Council of Europe Publications.

Bogdanovskaia, I. (1999). The legislative bodies in the law-making process. Retrieved September 20, 2017, from http://www.nato.int/acad/fellow/97-99/bogdanovskaia.pdf/

Burnley, R. (2015). Legal focus: Public funding principles for public service media. Geneva: European Broadcasting Union.

Car, V. (2007). Digital television in Croatia: Is television becoming a new media? Medij. istraž (god. 13, br. 2), 5-21.

Conde, N. (2009). PSM ombudsman, "Responsiveness and Accountability". Proceedings from The Consultation Meeting of The Ad hoc Advisory Group on Public Service Media Governance, Strasbourg, 17 and 18 September 2009.

Council of Europe. (1996). Recommendation 96 (10) of the Committee of Ministers to member states on the guarantee of the independence of public service broadcasting. Retrieved September 20, 2017, from https://rm.coe.int/168050c770

Council of Europe. (2007). Recommendation CM/Rec(2007)3 of the Committee of Ministers to member states on the remit of public service media in the information society. Retrieved September 20, 2017, from https://wcd.coe.int/ViewDoc.jsp?id=1089759

Council of Europe. (2012a). Declaration of the Committee of Ministers on Public Service Media Governance. Retrieved

${ }^{14}$ Such strategies are rooted in the Council of Europe Parliamentary Assembly Resolution 1142 (1997) dedicated to the relationships between parliaments and the media. 
September 20, 2017, from https://wcd.coe.int/ViewDoc.jsp?id=1908241

Council of Europe. (2012b). Recommendation CM/Rec(2012)1of the Committee of Ministers to member States on public service media governance. $\quad$ Retrieved $\quad$ September $\quad 20, \quad$ 2017, from https://search.coe.int/cm/Pages/result_details.aspx?ObjectID=09000016805cb4b4

Dorsen, N., Rosenfeld, M., Sajo, A., \& Baer, S. (2003). Comparative constitutionalism: Cases and materials. American Casebook Series, USA Thomson West.

Eberle, C. E. (2002). The regulation of public service broadcasting. Retrieved September 20, 2017, from http://www.epra.org/attachments/ljubljana-plenary-1-the-regulation-of-psb-keynote

EBU research shows strong public service media contributes to a healthy democracy. (2016). Retrieved September 20, 2017, from https://www.ebu.ch/news/2016/08/ebu-research-shows-strong-public-service-media-contributes-to-a-healthy-democracy

EBU Values Review: The Tool. (n.d.). Retrieved September 20, 2017, from https://www.ebu.ch/files/live/sites/ebu/files/Publications/EBU-PSM-Values-Review-Tool.pdf

EBU. (2012). Empowering society: A declaration on the core values of public service media. Geneva: European Broadcasting Union.

EBU. (2016) Parliamentary broadcast services in Europe. Retrieved September 20, 2017, from https://www.ebu.ch/files/live/sites/ebu/files/Publications/MIS/login_only/market_insights/EBU-MIS\%20-\%20Parliamentary $\% 20$ Broadcast $\% 20$ Services\%20in\%20Europe.pdf

EBU. (2016). Correlations links between public service media and societal well-being. Retrieved September 20, 2017, from https://www.ebu.ch/files/live/sites/ebu/files/Publications/MIS/login_only/psm/EBU-MIS\%20-\%20PSM\%20Correlations\%20 $-\% 20$ Public.pdf

European Court of Human Rights (Fourth Section), judgment in the case of Manole a.o. v Moldova, Application no. 13936/02 of 17 September 2009. (2009). Retrieved $20 \quad$ September, 2017, from https://hudoc.echr.coe.int/eng\#\{\%22ecli\%22:[\%222009:0917JUD001393602\%22],\%22itemid\%22:[\%22001-94075\%22]\}

European Court of Human Rights, admissibility decision in the case of Radio France and others v. France, 23 September 2003, No. 53984/00. (2003). Retrieved $20 \quad$ September, 2017 , from http://actu.dalloz-etudiant.fr/fileadmin/actualites/pdfs/AVRIL_2013/AFFAIRE_RADIO_FRANCE_ET_AUTRES_c._FRAN CE.pdf

European Parliament resolution of 25 November 2010 on public service broadcasting in the digital era: The future of the dual system (2010/2028(INI). (2010). Retrieved $\quad$ September $20, \quad 2017$, from http://www.europarl.europa.eu/sides/getDoc.do?pubRef=-//EP//TEXT+TA+P7-TA-2010-0438+0+DOC+XML+V0//EN

Freedom House. (2012). Slovakia. Country report. Nations in transit. Retrieved September 20, 2017, from https://freedomhouse.org/report/nations-transit/2012/slovakia

Herman, M. (2016). In Poland, a media grab signals rising power of nationalists, Columbia journalism review, 25.02 .2016$. Retrieved September 20,2017, from https://www.cjr.org/analysis/poland_media.php/

International conference "National public service broadcasting in Bosnia and Herzegovina". (2017). Recommendations. Retrieved September 20, 2017, from https://www.ebu.ch/files/live/sites/ebu/files/News/2017/06/Final\%20Recommendations\%20.pdf/

Inter-Parliamentary Union. (2017). Retrieved September 20, 2017, from https://beta.ipu.org/strong-parliaments/

IRIS. (2015). Online activities of public service media: Remit and financing. Strasbourg: European Audiovisual Observatory.

Jakubowicz, K. (2011). Media revolution in Europe: Ahead of the curve. Strasbourg. Council of Europe Publishing.

Jakubowicz, K. (2013a). Media and democracy in the 21st century: Searching for new models. Warsaw: Poltext Ltd.

Jakubowicz, K. (2013b). Preface. Broadcasting regulatory authorities: Work in progress. In W. Schultz, P. Walke, \& K. Irion (eds.), The independence of the media and its regulatory agencies: Shedding new light on formal and actual independence against the national context. Intellect Bristol, UK, Chicago, USA. Kindle edition.

Jędrzejowska, I. (2012). Democratic scrutiny, transparency, and modalities of vote in the National Parliaments of the Member States and in the European Parliament. Retrieved September 20, 2017, from http://www.europarl.europa.eu/RegData/etudes/note/join/2012/462506/IPOL-AFCO_NT(2012)462506_EN.pdf

Klinger, U. (2016). Accountability mehcnisms and the control of public service media in Europe. In K. A. Ibarra, E. Novak, \& R. Kuhn (Eds.), Public service media in Europe: A comparative approach (pp. 189-208). London and New York: Routledge.

Leurdijk, A. (2006). Public service broadcasting dilemma's and regulation in a converging media landscape. Retrieved September 20, 2017, from http://ripeat.org/wp-content/uploads/2010/03/Leurdijk.pdf

Lubenow, J. A. (2012). Public sphere and deliberative democracy in Jürgen Habermas: Theorethical model and critical discourses. 
American Journal of Sociological Research, 2(4), 58-71.

Mapping digital media: Global findings. (2014). Digital journalism: making news, breaking news. Open Society Foundations. $\begin{array}{lllll}\text { Retrieved } & \text { September } & 20, & 2017, & \text { from }\end{array}$ https://www.opensocietyfoundations.org/sites/default/files/mapping-digital-media-overviews-20140828.pdf

Marko, D. (2016). The future of public service broadcasting in the Western Balkans: The need for a new paradigm. Retrieved $\begin{array}{llll}\text { September } 20, & 2017, & \text { from }\end{array}$ http://www.analitika.ba/en/publications/buducnost-javnih-servisa-na-zapadnom-balkanu-u-potrazi-za-novom-paradigmom/

Medmedia. (2017). Why are public service media reforms proceeding at a snail's pace?. Retrieved September 20, 2017, from http://www.med-media.eu/public-service-media-reforms-proceeding-snails-pace/

Muižnieks, N. (2017). Public Service Broadcasting Under Threat In Europe, Says Commissioner for Human Rights, Strasbourg, 2 May 2017, Council of Europe, Platform to promote the protection of journalism and safety of journalists. Retrieved September 20, 2017 from http://www.coe.int/en/web/media-freedom/-/public-service-broadcasting-under-threat-in-europe/.

Nikoltchev, S. (2013). Public service media in a connected environment: Different shades of using new opportunities. Retrieved September 20, 2017, from https://epra3-production.s3.amazonaws.com/attachments/files/2154/original/PSM_Nikoltchev_final_2405.pdf/

Parliamentary Assembly of the Council of Europe (PACE). (1997). Resolution 1142 on parliaments and the media. Retrieved September 20, 2017, from https://rm.coe.int/16806461f9

Parliamentary Assembly of the Council of Europe (PACE). (2008). Resolution 1636 (2008) Indicators for media in a democracy. $\begin{array}{llll}\text { Retrieved } & \text { September } & 20, & 2017,\end{array}$ http://assembly.coe.int/nw/xml/XRef/Xref-XML2HTML-EN.asp?fileid=19474\&lang=en

Parliamentary Assembly of the Council of Europe (PACE). (2009). Recommendation 1878 (2009) Funding of public service $\begin{array}{lllll}\text { broadcasting. } & \text { Retrieved } & \text { September } & 20, & 2017,\end{array}$ http://assembly.coe.int/nw/xml/XRef/Xref-XML2HTML-en.asp?fileid=17763\&lang=en

Parliamentary Assembly of the Council of Europe (PACE). (2013). Resolution 1920 (2013) The state of media freedom in Europe. $\begin{array}{llll}\text { Retrieved } \quad \text { September } & 20, & 2017,\end{array}$ http://assembly.coe.int/nw/xml/XRef/Xref-XML2HTML-EN.asp?fileid=19474\&lang=en

Paun, C. (2016). Romanian lawmakers cancel public broadcaster fees, President seems sympathetic to criticism, Politico, 26.10.2016. $\quad$ Retrieved September $\quad 20, \quad$ from http://www.politico.eu/article/romanian-lawmakers-cancel-public-broadcaster-fees-klaus-iohannis-dacian-ciolos-european-br oadcasting-union/

Petkovic, B., \& Hrvatin, S. B. (2017). Public service media in South East Europe: Can the giants be taken from the grip of political interests? Observatorio balcani e caucaso transeuropa, 21.03.2017. Retrieved September 20, 2017, from https://www.balcanicaucaso.org/eng/Areas/Balkans/Public-service-media-in-South-East-Europe-Can-the-giants-be-taken-fro m-the-grip-of-political-interests-178672

Polyák, G. (2015). Hungary: New Amendment to the Media Act, IRIS 2015-2:1/22. Retrieved September 20, 2017, from http://merlin.obs.coe.int/iris/2015/2/article22.en.html

Public service media according to constitutional jurisprudence - the human rights and constitutional law dimension of the role, remit and independence. Study Based on Reports and Comparative Analysis (Europe (Council of Europe \& European Union), France, Germany, Hungary, Italy, Poland and Spain). (2009). Saarbrücken, 2 July 2009. Institut für Europäisches $\begin{array}{lllllll}\text { Medienrecht } & \text { e.V. } & \text { (EMR). } & \text { Retrieved } & \text { September } & 20, & 2017\end{array}$ https://www.ebu.ch/files/live/sites/ebu/files/Publications/EMR\%20Study\%20-\%202nd\%20version.pdf/

Public service media and democracy. Prague, 10-11 November. (2016). Conclusions and recommendations by the conference $\begin{array}{lllll}\text { participants. } & \text { Retrieved } & \text { September } & 20, & 2017,\end{array}$ https://www.ebu.ch/files/live/sites/ebu/files/News/2016/11/Final\%20conclusions\%20Prague\%2014112016\%2017.43.pdf

Public service media. Centre for Media and Communications Studies. (n.d.). Retrieved September 20, 2017, from http://medialaws.ceu.hu/public_service_media_more.html/

Sajo, A. (1999). Limiting government: An introduction to constitutionalis. Budapest, Central European University Press.

Schmitter, P. C., \& Trechsel, A. H. (2004). The future of democracy-Trends, analyses and reforms. Strasbourg: Council of Europe Publishing.

Shekhovtsov, A. (2016). Is transition reversible? The case of Central Europe. Retrieved September 20, 2017, from https://lif.blob.core.windows.net/lif/docs/default-source/publications/is-transiting-reversible-the-case-of-central-europe-janua 
ry-2016.pdf?sfvrsn=4/

Sunstein, C. (1994). A republic of reasons. In J. Garvey, \& T. A. Aleinikoff (Eds.), Modern constitutional theory: A reader (pp. 53-66). USA, West Publishing Co.

Tambini, D. (2015). Problems and solutions for public service broadcasting: Reflections on a fifty six country study. In K. A. Ibarra, E. Novak, \& R. Kuhn (Eds.), Public service media in Europe: A comparative approach (pp. 41-53). London and New York: Routledge.

Van den Bulck, H. (2016). Public service media accountability in recent decades: A progressive shift from state to market. In K. A. Ibarra, E. Novak, \& R. Kuhn (Eds.), Public service media in Europe: A comparative approach (pp. 73-89). London and New York: Routledge.

Wagner, M., \& Berg, A. K. (2015). Legal focus: Governance principles for public service media. European Broadcasting Union.

Zankova, B. (2014). Governance, accountability and transparency of public service media in a contemporary mediatised world: The case of Bulgaria. In M. Głowacki, \& L. Jackson (Eds.), Public media management for the twenty-first century: Creativity, innovation and interaction (pp. 125-142). New York and London: Routledge.

Zankova, B. (2017). Public service media regulation in the new media environment: The role of the networks for accelerating reforms. In M. Głowacki, \& A. Jaskiernia (Eds.), Public service media renewal: Adaptation to digital network challenges (pp. 17-39. forthcoming). Frankfurt am Main $\bullet$ Bern $\bullet$ Bruxelles $\bullet$ New York $\bullet$ Oxford $\bullet$ Warszawa $\bullet$ Wien: Peter Lang edition. 